\title{
СОЕДИНЕНИЯ ЗОЛОТА И РУТЕНИЯ \\ С ФОСФИТНЫМИ ЛИГАНДАМИ НА ОСНОВЕ ГЛЮКОЗЫ КАК ПЕРСПЕКТИВНЫЕ АНТИПРОЛИФЕРАТИВНЫЕ АГЕНТЫ
}

\section{М.Р. Гончар, Е.М. Матнуров, Ф.С. Нинин, Е.Р. Милаева, А.А Назаров}

Московский государственный университет им. М.В. Ломоносова, Москва, 119991, Росссия, Ленинские горы, д. 1, с. 3.

DOI: 10.19163/MedChemRussia2021-2021-129

Email:mari.kainas@yandex.ru

Поиск альтернативы платины в металлосодержащих противоопухолевых препаратах является одной из значимых задач в современной медицинской химии. Рутений и золото проявили себя как перспективные аналоги платины в разработке новых антипролиферативных агентов.

Целью данной работы явилось получение соединений золота и рутения с фосфитнымилигандами на основе глюкозы, а также изучение их физикохимических и биологических свойств с целью отбора данных комплексов в потенциальные лекарственные препараты.

Были получены новые комплексы золота и рутения с фрагментом биологически активного вещества - бексаротена.

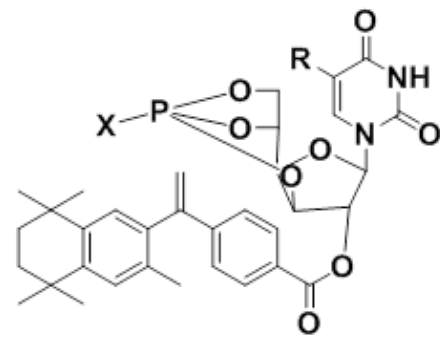

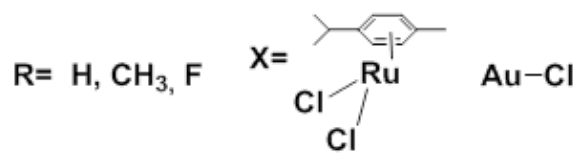

Puc. 1. Комплексы Аи и Rи на основе бициклофосфитов

Антипролиферативная активность новых комплексов была изучена на раковых линиях человека (MCF-7, A549, НCT116, WI-38) с использованием МТТ-теста.

Работа выполнена при финансовой поддержке грантов РФФИ№20-33-90081 u №19-53-12042 